\title{
Helicropping - early adopters' experiences
}

P.M.S. LANE ${ }^{1}$ and B.E. WILLOUGHBY ${ }^{2}$

${ }^{1}$ Ballance Agri-Nutrients, PO Box 390, Cambridge 3450, New Zealand ${ }^{2}$ Ecometric Consulting Limited, 42 Links View Drive, Omokoroa 3217, New Zealand

murray.lane@ballance.co.nz

\section{Abstract}

Aerial establishment of pasture and crops in hill country in New Zealand has received mixed publicity. Popularly referred to as 'spray and pray' this detracts from the success some practitioners have achieved with 'helicropping', a highly structured process that has the potential to markedly change hill country farming. Four farmers with an average of 4.5 years (range 2 to 7 years) of helicropping in New Zealand hill country were interviewed using a semi-structured snowball technique. Cross-case analysis was used to analyse themes of learning experience of helicropping, crop establishment, utilisation and economics, and the management of potential risk of soil loss from hill country cropping and harvest. Generally, all aspects ranked highly in terms of success. However, there was a strong message that this was attributable to strictly following a prescribed process that reduced risks both to a profitable return and to soil conservation.

Keywords: hill country, soil conservation, pasture renovation, no tillage

\section{Introduction}

Applying seed aerially to hill country inaccessible tractors (for cultivation) is not a new concept. With the advent of aerial topdressing in the late 1940s as capable and reliable post World War II aeroplanes became available, farmers mixed grass seed with fertiliser with variable results in terms of pasture establishment. To enable the seeds to reach the soil surface a 'hoof and tooth' practise was used to reduce pasture cover and trample in the seed. Research confirms this practise was effective in enhancing seedling establishment (Lambert et al. 1985; Macfarlane et al. 1986; Gillespie et al 2006), and with salt application increasing the palatability and hence pasture cover reduction in some situations (Gillespie et al. 2006).

The same issues were being grappled with and the same solutions utilised in 2013 (Douglas et al. 2013). However, the vulnerability of hill country soils to erosion and the downstream effects in terms of nutrients, suspended solids and loss of surface water quality are now better understood. With pressure for increased productivity, farmers are turning to the hill country as a cheaper development option. Hill country under $1000 \mathrm{~m}$ altitude with slopes greater than 20 degrees comprises around $40 \%$ of productive land in New Zealand. Zealand ncreased productivity from genetically improved pasture species and successful crop establishment may increase the hill country contribution to New Zealand Gross Domestic Product (Lane \& Willoughby 2016).

This paper documents the experiences of four hil country farmers who have explored the boundaries and economic practicalities of helicropping to gain better production, while mindful of their custodial environmental role.

\section{Methods}

Three broad themes were explored in semi-structured interviews with each of the four farmers (Galetta 2013) The themes, couched within the context of helicropping included: farm systems (how helicropping fitted into the wider scheme of individual farm practises), economics (the profitability of helicropping) and environment (the impact of helicropping on soil quality). The object of the interviews theme with each interviewee until no new information was forthcoming. The information was interpreted from interview transcripts by themes and summaries of themes made by cross-case analysis. The information forming the basis of this qualitative study is presented as verbatim quotes from the interviews as italicised statements.

The four properties were in the central North Island. Three of the interviewees owned more than one property.

\section{Farmer A}

Operation: Overwintering young stock.

Farm: 1000 ha at an altitude of 550 to $600 \mathrm{~m}$, annual rainfall averaging $1300 \mathrm{~mm}$ (winter dominant). Overwintering 1400 calves, 1400 heifers and a few bulls.

Helicropping experience: 7 years.

\section{Farmer B}

Operation: Breeding, finishing and dairy support. Farm: 430 ha (300 ha effective, balance in native bush) at an altitude of 140 to $570 \mathrm{~m}$, annual rainfall averaging 1800-2200 mm (winter dominant). Overwintering 4200 stock units.

Helicropping experience: 4 years. 


\section{Famer C}

Operation: Beef and lamb finishing.

Farm: 520 ha at an altitude of 100 to $500 \mathrm{~m}$, annual rainfall averaging 1200-1550 $\mathrm{mm}$ (winter dominant) Overwintering 7500 stock units.

Helicropping experience: 2 years.

\section{Farmer D}

Operation: Lamb breeding and finishing.

Farm: 890 ha at an altitude of 200 to $457 \mathrm{~m}$, annua rainfall averaging $1100 \mathrm{~mm}$ (winter dominant). Overwintering 4000 lambs, 3200 ewes, 180 cows 145 (rising 2-year old) heifers, 145 (rising 2-year old steers, 290 weaners, 50 (rising 3-year old) steers.

Helicropping experience: 5 years.

\section{Results and Discussion}

Respondents felt that much of the information required for successful helicropping was available for crop establishment. However, there was little in the way of formal support around decision making and much of their early efforts were by "Trial and error", "it's a technique that needs to be developed.... we needed to find some solutions and kept working on it till we found the solutions", "we started off from 10 ha and just tried different ways of achieving a good result".

With an average of 4.5 years (range 2 to 7 years) experience with helicropping all interviewees indicated they had a method that worked for them on thei property, provided profitable returns along with soil protection from erosion. By inference there may have been experiences along the way that were less than fully successful. However, there was a clear message that the practice of helicropping was something they wished to continue to develop.

Economic viability of successful helicropping was seen as a "Game changer", "and changing the face of hill country farming".

The key ingredient was the availability of winter feed in the form of kale or swedes, allowing growth of young stock (lambs, rising 1-year old or rising 2-year old heifers or steers) preparing them to "Better utilise the spring flush". "It means we don't have to thrash the runoff." Implying that the cost of maintaining stock over winter on hill country farms was incurred offfarm "We can beat the rush to market" was a common theme. Growing rather than maintaining stock ove winter allowed target weight gains to be achieved earlier than hill country farmers relying on spring feed to fatten their animals.

The process to establish a helicrop was described by all participants as straightforward and simple. "All it took was a telephone call and an email to the helicopter pilot with the GPS co-ordinates for the paddock to be sown", "not even a gate to be opened", "I arranged it all over the phone". However, this belies the fact that there has been considerable planning before initiating the contract. Soil tests and any deficits in soil fertility need to be corrected a year before the crop is sown. In some cases this involves "Capital dressing" or large amounts of lime to be applied to "Fix the pH of soil". While there was general acknowledgment that "The information is all there to establish a good range of crops" much of the detail on individual farms had to be established by trial and error. Success was "Guaranteed by following a recipe" and to "Leave a step out is inviting failure", "as long as you follow all the rules not just some of them" and "no shortcuts"

This attitude was common to all participants when establishing a helicrop, where the additional cost of slug bait and insecticide to protect the emerging seedlings was seen as "Essential insurance". When financial constraints emerge there may be strong pressure to forgo this insurace with potentilly severe (a) econonic and forve. Insect pest risks are specific to crop type and must be managed with a good knowledge of the tools available, whether identification or treatment. "I was creating a monoculture .... then along came the insects". In this instance confusion over both pest identification and solution "Almost put me out of business". This was an isolated example of misfortune that in this instance was "Brealing the whole system". It filed to deter the farmer from helicropping and was just one of six different crop species he had successfully established. Costs pertaining to crop establishment varied from around $\$ 1000$ to $\$ 1500 /$ ha with the variation largely around helicopter costs including travel time to site, number of visits to the site and size of area treated. These costs were similar to those incurred with more traditional ground-based equipment used for cultivation (Lane \& Willoughby 2016). There were financial (Lane \& Wilong 2016). There were Anancial ter base and ensuring that as many operations as possible, including herbicide spraying, seed, fertiliser and insurance application (slug bait and insecticide), were completed in the one day. Additional helicopter costs could be incurred should intervention be required for pest or weed management later. Opinions varied as to the size and capacity of helicopter required from small "You get a much better job with a small brush" to "The big get achines carry a lob more". Obviouly differen siz machines have differing costs and this along with the type of terrain to be flown must dictate which machine is best for the job. Helicopters may be constrained by wind, rain and low cloud, but as "You're not putting a wheel on the paddock" sowing can be undertaken with high soil moistures. An interesting side-line around these comments about reducing vehicular traffic on the farm related to health and safety issues. "Good to get the tractors off my place. It's an accident waiting to happen". "I worry every time the contractor (tractor) is working the place that he'll tip the thing". The idea that helicopters may be safer is questionable.

Utilising suitable spray technology, in particular Accu-Flo ${ }^{\mathrm{TM}}$ boom nozzles substantially reduces spray drift and permitted accurate spray placement to within $2 \mathrm{~m}$ - "He (helicopter pilot) is spraying willows in our conservation area, now amongst my oak trees...... can spray a willow tree and leave my oak tree which is 2 $m$ away without any damage". The precision of the spraying was further emphasised "He applies half rates in a half overlap pattern to improve coverage on uneven terrain". Improved spreader technology means "He (helicopter pilot) can spread $4 \mathrm{~kg}$ (per ha) swede seed quite accurately without mixing with other products".

An appreciation of the role improved technology in helicopters and application hardware was a feature in all interve (e.g. soture of all interviews two different hopper sizes; a small one with greater measurement accuracy for seed and slug-bait, and a
larger one for fertiliser) has improved the reliability of establishing helicrops in hill country; combined with the accuracy of GPS flying for both speed and location has resulted in precise pesticide, seed and fertiliser application.

Winter was seen as a good time to engage the helicopter operator in discussions and planning for the upcoming spring programme (being a downthe upcoming spring programme (being a downparties understood the extent and complexities of the

parties understood the extent and comp
forthcoming helicropping operation.

Plant residues post-herbicide spraying were seen as valuable in conserving soil moisture particularly as spring conditions turned to summer "September October is optimum ...as soil moisture is traditionally, pretty good", "we go wholly and solely with $2500 \mathrm{~kg}$ cover when cover when spraying", "cover keeps the soll moisture up'. However, "Cover is an ideal base for insect pests", "slugs in the cover". These statements illustrate a belief that the post-herbicide dead plant residues play a role in conserving soil moisture through soil cover and in the absence of transpiration losses. These observations agree with the work of Tozer et al. (2016) who measured higher soil moisture retention under plant residues compared to bare ground in the Waikato region. However, there was an acknowledged risk of the plant residue harbouring pests such as slugs.

The popular practice was establishing swedes (Brassica napus) in the first year "Swedes in the first year and in the spring we followed pretty much the same procedure with kale". Kale (Brassica olercaea) was used in year two, with the pasture species or chicory (Cichorium intybus) sown in year three. "Into new grass so the moment that the animals walk out of the crop at the end of July, early August, we get the chopper straight back and aerial spray grass seed".

Varying the plantings was seen necessary to avoid build-up of disease such as club root (Plasmodiaphora brassicae), and was the practice of each farmer.

Crop utilisation was generally described as straight forward. Effective paddock subdivision on the steeper hill country was raised as an issue "Fighting your way hrough shoulder height tale to nu a hot wire is no fun" llustrates one handicap. Suggestions the is using cap. Suggestions that using the the helicopters, buffer recto le tow paddock subdivision with an electric wire. A strip following the paddock contour may also serve as a sediment intercept Another grazing option promulgated was low intensity set stocking over the period of crop utilisation "If there is plenty of feed happy cattle don't move around much"

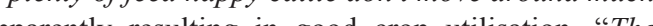
(liveweight gain) on over the winter". I was observed that there was "No sign of tracking or widespread soil disturbance". It was interesting to note that helicropped turnips resulted in the bulb "sitting on the soil surface" and not having to be "pulled out of the ground by stock" as would be the case with a cultivated or drilled crop. This may be attributable to a varietal difference, although this information was not elicited.

Response to observations of and risk management for soil loss were varied from "I never do a paddock with steep faces" and "I don't touch the light soils" to "I plan to re-grass the whole farm using helicropping". A common response to delving into the theme of managing soils was that "At the first indication there might be heavy rain I take the stock off" and "I never leave the stock on if it's raining".

Only one of the farmers introduced direct interventions such as bunds or buffer strips to manage soil and nutrient loss across all four properties there was soil loss was to be guarded against. "We are very conscious of its (soil loss) potential to happen". Along with the awareness were statements that conveyed a desire to ensure soil loss did not happen. "Start at the top of the catchment for grazing", "because you're not cultivating the risk is much less", "consider sediment bunds at the bottom of the paddock" to "the technology allows us to avoid all our conservation strips". In the absence of measurements, these responses were based on observation and rationalisation. Observations such as sediment contribution to streams "hasn't coloured up any more in the rain" cannot be taken as reliable unless all rainfall events are observed and the source of the turbidity identified. Certainly, in the absence of cultivation the soil is likely to retain its structure and percolation capacity. At the time of crop utilisation, 
with stock on the crop, there is an added component to soil loss risk depending on grazing management and stock type.

A consistent response across all themes was the necessity to "Make sure you do it properly to make sure you get a good crop", "you can't cut corners".

It was clear from the interviews that the detail of successfully establishing crops devolved to the farm level based on the quality of decisions such as fertiliser requirements in relation to soil nutrient levels and crop requirements, and potential for weed and pest impacts. The choice of crop was determined by the type and/ or class of animal for which it was targeted, with the area determined by both availability and crop volume to sustain or grow animals. Differences in the pattern of seasonal rainfall dictated when to establish a helicrop, and were based on soil moisture rather than a calendar event. Delaying a decision until soil temperatures were suitable was clearly outweighed by considerations of soil moisture and ensuring the crop was established well before the soils dried out.

The preceding dialogs record the experiences of the four interviewees at a time when all have come through the initial learning experiences for helicropping. Attention needs to be paid to their experiences and what might be done in the future if other hill country farmers are to take up the practice of helicropping with confidence.

\section{Conclusions}

All four respondents reported profitable returns from their experiences with helicropping. Combined with their experiences of reliable crop establishment this has convinced these early adopters that the practice was a good fit within their farming practices and did not conflict with their obligations as environmenta custodians looking to preserve hill country soils. Their che experiences fit well with the Pastoral Industry Forage nt and on-farm innovation (Forage Strategy 2016).

\section{ACKNOWLEDGEMENTS}

The authors acknowledge the generous input from Colin Armer, Paul Bodle, Geoff Fitzgerald and Mark Grace in sharing their experiences while using helicropping that are recorded in this paper.

\section{REFERENCES}

Douglas, G.B.; Tozer, K.N.; Cameron, C.A.; Fraser, T.J.; Muir, P.D.; Moss, R.A.; Rennie, G.M.; Knight, T.L. 2013. Successful establishment of oversown chicory and plantain on uncultivable hill country. Proceedings of the $22^{\text {nd }}$ International Grassland Congress: 523-524.

Galetta, A. 2013. Mastering the semi-structured interview and beyond: from research design to analysis and publication. New York University Press.

Gillespie, B.J.; Lucas, R.J.; Moot, D.J.; Edwards G.R. 2006. Can topdressing with salt increase oversowing success and pasture quality on steep, south facing slopes in hill country pastures? Proceedings of New Zealand Grassland Association 68: 349-353.

Lane, P.M.S.; Willoughby, B.E. 2016. Hill country cropping with no land-based equipment. Grassland Research and Practice Series 16: 251-256.

Lambert, M.G.; Rhodes, A.P.; Barker, D.J.; Bircham, J.S. 1985. Establishing and managing improved plants in hill country. Grassland Research and Practice Series 3: 31-34.

Macfarlane, M.J.; Bonish, P.M. 1986. Oversowing white clover into cleared and unimproved North Island hill country. The role of management, fertiliser, inoculation, pelleting and resident rhizobia. Proceedings of New Zealand Grassland Association 47: 43-51

Pastoral Industry Forage Strategy. 2016-2036. https// www.nzgajournal.org.nz/index.php/JoNZG/about/ contact

Tozer, K.N.; Moss, R.A.; Cameron, C.A.; Rennie, G.M.; Douglas, G.B. 2016. Litter can enhance pasture establishment on non-cultivable hill country. Grassland Research and Practice Series 16: 243250.

Tozer, K.N.; Douglas, G.B. 2016. Pasture establishment on non-cultivable hill country: a review of the New Zealand literature. Grassland Research and Practice Series 16: 213-224.

\section{Information required from research programmes when introducing legume forage systems into challenging environments}

T.A. NELSON ${ }^{1}$, S.M. ZYDENBOS ${ }^{2}$ and D.R. STEVENS ${ }^{3}$ ${ }^{1}$ AgResearch, Ruakura Research Centre, Private Bag 3123, Hamilton 3240, New Zealand ${ }^{2}$ AgResearch, Lincoln Research Centre, Private Bag 4749, Christchurch 8140, New Zealand ${ }^{3}$ AgResearch, Invermay Research Centre, Private Bag 50034, Mosgiel, New Zealand

tracy.nelson@agresearch.co.nz

Abstract

The use of legumes to increase animal performance is well known, but why are sheep and beef farmers not using a legume forage system in New Zealand hill country, and what information do they need before introducing a legume forage system? A co-innovation process was started to explore the challenges sheep and beef farmers face introducing a legume forage system into hill country and their information needs. The first step in this process, reported here, was to run eight workshops throughout New Zealand which 105 farmers and agribusiness representatives attended. Results showed that getting the right information from trusted sources was the highest priority for farmers looking to introduce a legume forage system. Information provided by the science community and industry needs to be region specific as the range of knowledge around legume species differs across regions. Some of the information required by farmers is already well documented, but may not be in the hands of the right people.

Keywords: challenges, forage, farm system, information requirements, knowledge, legumes, sheep and beef farmers

\section{Introduction}

Evidence is emerging that pasture production in New Zealand hill country has declined in the past 10 to 15 years (Mackay \& Costall 2016), especially on some slopes and aspects. So while maintaining advances in productivity and profitability by utilising more of the feed grown (Fennessey et al. 2016), this option is rapidly running out. New technologies are required to maintain productivity and profitability into the future. Hill country development and sustainability are hampered by limitations of soil nitrogen and water. Legumes, by fixing atmosheic $\mathrm{N}$, incense water use effien, fixing atmospheric $\mathrm{N}$ and supply high quality feed to ewes and lambs and cows and calves, providing stock for red meat supply at premium times. Previous science developing forage legumes has often failed as farming practices have not changed to capture the benefits of feed quality, improved water use efficiency and feed quantity, that are proven to increase animal production (Stevens et al. 2012).
The use of legumes to increase animal performance is well known (Lambert \& Litherland 2000), however, sheep and beef farmers are not adopting legume forage systems in New Zealand hill country. What information do they need before introducing such a system? This research reported aimed to understand the perceived challenges farmers face when introducing a legume forage system and what information requirements lopt wuch a system. This paper reports e to make a change to their farm system. Such information will help researchers incorporate these needs into research programmes.

\section{Methods}

For complex issues, such as changing a farm system, a co-innovation approach can assist with change (Turne et al. 2014). This approach involves a number of people and organisations working together in the design and implementation of research. A co-innovation process was used to explore the challenges and information requirements when introducing a legume forage system into hill country. A benefit of 'co-innovation' is better understanding of the problems as a result of involving more people and organisations, which in turn provides reater confidence that the solutions will be successful ( through a process of interaction and social learning, become aware of the values and needs of participants in the co-innovation system. Ideally, this enhances each person's moral and knowledge perspectives and increases their respect and opportunity for developing a solution that attempts to satisfy the needs of all (Hounkonnou et al. 2012; Klerkx et al. 2012; Klerkx \& Nettle 2013). The hypothesis was, if people and organisations from all parts of the system are involved in specifying the problem and co-developing a solution, then that solution is more likely to be fit-for-purpose and be adopted by the end-users (who helped develop it) than would otherwise be the case.

Workshops

Eight farmer workshops were held throughout New 